\title{
The Importance of the Role of Teacher Professionalism in the 21st Century Education Process at SD Segoroyoso Bantul Yogyakarta
}

\author{
Suci Muzfirah ${ }^{(1)}$ \\ ${ }^{1}$ UIN Sunan Kalijaga Yogyakarta, Indonesia \\ Email: 1 19204080044@student.uin-suka.ac.id
}

\begin{abstract}
Abstrak: Education is currently in the era of education 4.0 or can be called 21 st century education. Where the educational process changes so rapidly with the help of technology. Teachers play an important role in carrying out functions and realizing national educational objectives. The purpose of this research is to see how and to what extent teacher self-reflection has contributed to educational development efforts in the 21st century as a professional teacher. This study involved 2 teachers at SD Segoroyoso Bantul. Where the 2 teachers are already certified and some are not yet certified. The method used is descriptive qualitative method with data retrieval using interviews and documentation. The results of the study can be stated that to become a professional teacher does not have to be certified
\end{abstract}

\begin{tabular}{l}
\hline Tersedia Online di \\
\hline http://journal.unublitar.ac.id/pendidi \\
\hline kan/index.php/Riset_Konseptual \\
\hline Sejarah Artikel \\
\hline Diterima pada : 06-03-2021 \\
Disetuji pada : 14-04-2021 \\
Dipublikasikan pada : 30-04-2021 \\
\hline Kata Kunci: \\
\hline Professionalism, 21st Century Education, \\
Teacher Certification \\
DOI: \\
http://doi.org/10.28926/riset_konseptual.v5i \\
2.334
\end{tabular}
first. Important components to becoming a professional teacher are 24 teacher administration, 4 teacher competencies (pedagogic, personality, professional, social), understanding the role of the teacher profession, and also understanding learning in the 21 st century (education era 4.0).

\section{PENDAHULUAN}

Education is needed by every human being as one of the capitals in order to succeed and achieve success in life. Education is a conscious effort of man in creating himself and society in order to maintain life in the current development of the times (Hidayat, 2013). Human patterns and lifestyles that are always changing towards the fulfillment of human needs, both physical and spiritual, then the quality of education must be improved and continuously updated. There is no denying that the quality of education in Indonesia is still far from expected. In a narrow and specific micro-perspective or review, the dominant factors that influence and contribute greatly to the quality of education are professional teachers and prosperous teachers. Therefore, teachers as a profession must be professional in carrying out various educational and teaching tasks, mentoring and training entrusted to him (Hadis \& Nurhayati B, 2014). The preamble to the 1945 Constitution states that one of the objectives of the Republic of Indonesia is to educate the nation's life and therefore every Indonesian citizen is entitled to a quality education in accordance with his interests and talents regardless of social status, race, ethnicity, religion, and gender. Equalization and quality of education will make Indonesian citizens have life skills so that they have the ability to know and overcome their problems themselves and the environment, encourage the establishment of civil society and modern imbued with the values of Pancasila (Riyadin, 2016). In order to achieve the national educational goal of smarting the life of the nation and developing the whole human being, it is needed the role of professional educators. 
Teachers are ideal figures who are expected to exist and their role in Education. There is a term, "No Teacher No Education, No Education No Economic and Social Development". The phrase describes the role of educators not only as mentors, but also as exemplary figures who have good characteristics. Thus, educators should be active from two directions, namely externally by directing or guiding learners, and internally by realizing noble moral characteristics (Kurniasih \& Sani, 2017). Teachers as the dominant micro-determining component of the quality of education must be qualified and perform well in the era of globalization and technology. In operational level, teachers are the determinants of educational success through their performance at the institutional, instructional, and experensial level. Depdikbud in (Hadis \& Nurhayati B, 2014) stated that teachers are human resources that are able to utilize other factors so as to create a quality teaching and learning process and be the main factor that determines the quality of education. Teachers must be trained in teaching, so teachers must follow trainings in order to have professional status. Realizing this, the Ministry of Education conducts a certification program in the form of teaching deed for graduates of educational and noneducational sciences who will become educators.

The challenge faced in the era of Industrial Revolution 4.0 is to prepare skills and mental to have an advantage in competition (competitive advantage). The path taken to prepare it all is through education. Students must be able to develop and improve their competence. That is, the challenge for teachers is to be ready to help students in developing the abilities of students. Teachers are required to be professional educators. Basically a professional has the meaning of expert (an expert) or specialist (a specialist). Processional is a work or activity performed by a person and becomes a source of income for life that requires skills, skills, or skills that meet certain quality standards or norms and have a professional education (Kurniasih \& Sani, 2017). While the teacher as a professional means that the work of a teacher can only be done by a person who has academic qualifications, competencies, and educator certificates in accordance with the requirements for each type and level of education.

Permendikbud number 87 year 2013 suggesting that the Teacher Professional Education program (PPG) is an educational program organized to prepare graduates of S1 education and S1 / DIV non-educational who have talents and interests to become teachers in order to master the competence of teachers in full in accordance with national standards of education so as to obtain a certificate of professional educators in early childhood education, primary education and secondary education. From the above problems there are two main things that need to be analyzed further, namely how the government's strategy in improving teacher professionalism and the role of PPG in improving the quality of education in Indonesia to deal with MEA. Therefore, PPG program is considered important to be developed and empowered, especially for LPTK in this MEA era (Pangestika \& Alfarisa, 2015). Teachers as professionals must meet several criteria, namely: first, have a commitment to students and the learning process. Second, master the subjects he teaches and how to teach them to students. Third, it is responsible for monitoring students' learning outcomes through various evaluation methods. And fourth, being able to think systematically about what he does and learn from his professional environment. In addition to teachers must meet some of these criteria, teachers must also be qualified for minimum academic and certification in accordance with the level of teaching authority. Teacher certification program will be a control that encourages education providers to improve their professionalism and provide maximum service to all interested parties or stakeholders. Basically the teaching and learning process is at the core of the overall education process, among which teachers are one of the important factors in determining the success of the teaching and learning process in the classroom (Ismaya, 2015). Therefore, teachers are required to improve their roles and competencies, competent teachers will be better able to create an effective learning environment and will be better able to manage the classroom.

Ratih in (Hadis \& Nurhayati B, 2014) suggest that to become a professional teacher, there are several skills that must be possessed by teachers, yiatu: first, 
explaining informing, showing how, initiating, directing, administering; second, unifying the group; third, giving security; fourth, clarifying attitudes, beliefs, problems; fifth, diagnosing learning; sixth, making curriculym materials; seventh, evaluating, recording, reporting; eighth, enrichment community activities; ninth, organizing and arranging classrooms; and tenth, participating in school activities. Each of these abilities should be applied by teachers to professionalism. Of course, professional teachers must always be creative and productive in innovating education. To become a professional teacher in the world of education, of course, depends heavily on the skills and level of education that he pursues, because the position of teacher is one of the professional positions. Professionals point to a job or position that demands professional expertise, responsibility, and loyalty (Alamsyah et al., 2020). A profession in theory cannot be done by just anyone who is not trained. In addition to education and training, the teacher's teaching experience also determines the quality of teachers in teaching. The more experience teachers have, the more knowledge they have. The more time it is expected that the teacher will have more experience. So, ideally if the level of education and teaching experience of teachers is increasing, then there should also be an increase in teacher professionalism.

From (Permendiknas, 2007) Number 16 mentioned professional competency standards that must be owned by teachers, as for the five aspects of competence are, as follows: First, mastering the material, structure, concepts and scientific mindsets containing the subjects that are mastered. Second, mastering the standard of competencies / core competencies and basic competencies in subjects / areas of development that are mastered. Third, develop creatively mastered subject matter. Fourth, develop professionally sustainably by performing reflective actions. Fifth, utilize information and communication technology to communicate and develop themselves. Competencies possessed by teachers are not limited to knowledge about professional tasks such as only knowing about ways of educating, teaching, guiding, directing, training, assessing, and evaluating, but that knowledge is not imbued and not applied by teachers consequently, consistently, and skillfully. It is certainly free for teachers to have such knowledge if it is not realized in action so as not to provide meaning and benefits for the implementation of education in real (Irwantoro \& Suryana, 2016).

In achieving a good quality of education is strongly influenced by the performance of teachers in carrying out their duties so that teacher performance becomes an important demand to achieve educational success. In general, the quality of good education becomes a benchmark for the success of performance shown by teachers. However, the fact shows that the quality of teachers in Indonesia is still relatively low. This is partly due to the unfulfillment of the quality of education. Therefore, teacher performance is highly considered, and strives to be continuously improved (Putri \& Imaniyati, 2017). Teacher performance in schools is influenced by several factors. These factors are the qualification factor of teacher standards and the relevance between the teacher's area of expertise and teaching assignments. But the problem now is that the motivation of work, performance, and professionalism of teachers in Indonesia is still low. The low quality of education in Indonesia is inseparable from the low quality of teachers as the main determinant of the quality of education. At SD Segoroyoso Bantul, there are teachers who have been certified and there are teachers who have not been certified. Can't teachers who haven't earned an educator's certificate yet be said to be professional teachers? How are the two performing in the process of educating and teaching?

Changes in learning and teaching patterns will certainly never be separated from the role of teachers, especially changes to online learning patterns. Teachers must be prepared for various learning conditions and student conditions, including the development of life in the community (Wahyono et al., 2020). Therefore, this article was created with the aim to see and review how to become a professional teacher in the pandemic, which is focused on reviewing aspects of the demands of digitalization in the world of education, especially on learning activities. The review will focus on how to 
become a professional teacher in education in Indonesia during the pandemic, the challenges faced and at the same time strategic solutions in the future. This research will discuss the importance of professional teachers in 21 st century education at SD Segoroyoso Bantul.

\section{METODE}

This research was conducted using qualitative research method. Qualitative research method is a method that examines objects that are natural. The type of research approach is a descriptive qualitative approach. The object of the study in this study is professional teachers at SD Segoroyo Bantul in carrying out 21st century education. The data was obtained using data collection techniques such as conducting unstructured interviews and documentation to 2 (two) teachers at SD Segoroyo Bantul. The sources of information used by researchers are textbooks, scientific articles, proceeding seminars that discuss the professionalism of teachers.

\section{HASIL dan PEMBAHASAN}

Professionalism is a need that can not be delayed anymore, the increasing competition is getting tighter in the era of globalization, it is necessary to increase the professionalism of a teacher. Professional is a job or activity performed by a person and becomes a source of income of life that requires skills or skills that meet certain qualities or norms and require professional education (Kristiawan \& Rahmat, 2018). To become a professional teacher, the components that must be fulfilled, namely: having teacher administration, having four competencies that must be possessed by teachers (pedagogic, personality, professional and social), understanding the role of teacher certification and understanding 21st century education.

\section{Teacher Administration and Competency}

Teacher administration and competence are important components for professional teachers. Because, with the complete administrative files created, it is one of the steps to be a professional teacher. Teacher administration consists of 24 files that certainly affect the quality of the teacher. From the results of interviews to 2 teachers at SD Segoroyoso Bantul, it can be concluded that not all of the administration is made by teachers, there are some files that have been given by the education center. When viewed from the status of certification, teachers who have not been certified are also able to complete 24 teacher administrative files. By seeking information either from college friends, principals, or sources from the internet media, the creation of such administration can be done. In the current situation, the creation of teacher administration files is being interrupted. Because in the teaching and learning process was done at home (Distance Learning). And there are some components that occur formatting changes. It's like making RPP. This rpp creation contains only 1 sheet. The less effective learning process also caused delays in the creation of teacher administration files. The 24 teacher administration files can be seen in the following table.

Tabel 1. Teacher Administration Components

\begin{tabular}{|c|c|c|}
\hline $\begin{array}{l}\text { Kalender } \\
\text { Pendidikan }\end{array}$ & $\begin{array}{l}\text { Jam Efektif dan } \\
\text { Analisis }\end{array}$ & Standar SKL \\
\hline $\begin{array}{l}\text { Pemetaan KD } \\
\text { dan Indikator }\end{array}$ & $\begin{array}{l}\text { Program } \\
\text { Tahunan }\end{array}$ & $\begin{array}{l}\text { Program } \\
\text { Semester }\end{array}$ \\
\hline $\begin{array}{l}\text { Penyusunan } \\
\text { Silabus }\end{array}$ & $\begin{array}{l}\text { Penyusunan } \\
\text { RPP }\end{array}$ & Penetapan KKM \\
\hline Buku Absen & $\begin{array}{l}\text { Daftar } \\
\text { Presentasi } \\
\text { Siswa }\end{array}$ & $\begin{array}{l}\text { Buku Agenda } \\
\text { Mengajar }\end{array}$ \\
\hline $\begin{array}{l}\text { Ulangan, tugas, } \\
\text { pr, UAS }\end{array}$ & $\begin{array}{l}\text { Analisis } \\
\text { Ulangan Harian }\end{array}$ & $\begin{array}{l}\text { Perbaikan dan } \\
\text { Pengayaan }\end{array}$ \\
\hline Bank Soal & Kisi-kisi Soal & Jurnal Kelas \\
\hline
\end{tabular}




\begin{tabular}{lll}
\hline $\begin{array}{l}\text { Pencapaian } \\
\begin{array}{l}\text { Target } \\
\text { Kurikulum }\end{array}\end{array}$ & $\begin{array}{l}\text { Buku Catatan } \\
\text { Khusus }\end{array}$ & $\begin{array}{l}\text { Buku Tamu } \\
\text { Supervisi }\end{array}$ \\
\hline Notulen Rapat & $\begin{array}{l}\text { Daftar } \\
\text { Inventaris }\end{array}$ & $\begin{array}{l}\text { Buku } \\
\text { Penyerahan } \\
\text { Rapot }\end{array}$ \\
\hline
\end{tabular}

Next are 4 (four) competencies that must be mastered by teachers. The first is pedagogic competence, which is the teacher's ability with regard to theoretical mastery and application process in learning. After conducting interviews with 2 (two) teachers at SD Segoroyoso Bantul, it can be concluded that the pedagogic competencies include: first, mastering the characteristics of learners; second, mastering the theory and principles of learning; third, develop the curriculum and design learning; fourth, conduct educational learning, utilize specific instructional objectives (ICT) for the purposes of learning; fifth, facilitate the development of potential learners; sixth, communicate effectively, empathetically, and politely with learners; seventh, conduct evaluation and assessment of learning processes and outcomes; eighth, utilizing the results of evaluation and assessment for the benefit of learning; and ninth, take reflective actions to improve the quality of learning. Personality Competency, which is a steady personality, noble character, wise, and authoritative and an example for learners. According to the teacher at SD Segoroyoso Bantul, a professional teacher can reflect attitudes and norms that suit the environment in the community. Moreover, students in the basic age are the Golden Age, where every speech and deeds of a more mature person will be imitated by it.

After that there is professional competence, which is the ability to master the subject matter broadly and deeply. For a certified teacher, he must be a professional teacher because a certified teacher has certainly carried out various professional training activities. But that doesn't mean uncertified teachers are unprofessional teachers. Seen from an interview to one of the teachers at SD Segoroyoso Bantul, that readiness in teaching is not seen from already certified or not. Moreover, in this online learning period teachers must be good at using various social media that can support learning so as to achieve learning goals. And the last is social competence, secured is the ability of teachers to communicate and interact effectively and efficiently with students, fellow teachers, parents / guardians of learners, and the surrounding community. Being a teacher for students at the elementary school level (SD/MI) does require a variety of skills and abilities. Have a broad insight into all subject matter, do so much teacher administration, understand every characteristic of learners, and also as an intermediary between children and parents. Here, the teacher is also a counseling supervisor. The development of each student's character is not entirely obtained from the school environment, but also from the home environment and the community environment. So, the teacher also conducted counseling with the guardians.

Education 4.0 brings teachers to be able to adapt, and willing to learn so that the quality can improve, and be able to compensate the millennial students, then teachers must continue to learn to improve competence so as to be able to face the millennial learners. According to Budiwibowo in (Supandi et al., 2020) teachers as transformational leadership figures who stimulate intellectually in carrying out tasks in accordance with technological skills. Each teacher must have different abilities, so professional trainings, educational seminars and educational workshops must be attended by teachers. By participating in various activities, teachers will gain experience and improve the quality of teachers in conducting the educational process.

\section{Role of Teacher Certification}

Judging from the current condition of Education in Indonesia, teachers still have not professionally carried out their duties and responsibilities. H.A.R Tilaar and Riant Nugroho in (Disas, 2017) ee the process of education as personality development includes a very wide range of efforts, there are various theories about personality, its 
structure, its development, and its purpose. The main basis for the implementation of certification is Law No. 14 of 2005 concerning Teachers and Lecturers (UUGD) which was passed on December 30, 2005. The article states it is article 8: teachers must have academic qualifications, competencies, educator certificates, physical and spiritual health, and have the ability to realize national educational goals.According to (Latiana, 2019) the purpose of teacher certification is the process of granting educator certificates to teachers. Educator certificates are awarded to teachers who meet the teacher's professional standards. Professional teachers are an absolute requirement to create quality educational systems and practices. While the educator certificate is a certificate signed by the college certification provider as a formal proof of recognition of teacher professionalism given to teachers as professionals.

An educator who already has a certificate, then directly people will conclude that he is a professional educator. Indications are, because he has passed the competency test. However, there is no guarantee that an educator who has passed the competency exam will become a professional educator, although the ideal level expected of such competency exams is to create a professional educator. Professionalism is a term obtained after going through a certain stage process. Because he has passed that particular stage, then he is called a professional (Latiana, 2019).The implementation of a major national activity such as teacher certification, certainly has a purpose and benefits for teachers. Teacher certification aims to: a) Determine the feasibility of teachers in carrying out duties as learning agents and realizing national educational objectives; b) Improving the process and quality of educational outcomes; c) Improving the dignity of teachers; and d) Improving teacher professionalism. The benefits that will be felt after teacher certification is implemented can be detailed as follows: Protecting the teacher's profession from incompetent practices, which can damage the image of the teacher's profession; Protecting the public from unqualified and unprofessional educational practices; To be a vehicle for quality assurance for LPTK, and quality control and number of teachers for users of education services; Keeping educational institutions (LPTK) from internal desires and external pressures that deviate from the prevailing provisions; and Improving teacher welfare with professional benefits. The advantages and disadvantages of PPG can be seen from the following table.

Tabel 2. Advantages and Disadvantages of PPG

\begin{tabular}{ll}
\hline \multicolumn{1}{c}{ Kelebihan PPG } & \multicolumn{2}{c}{ Kekurangan PPG } \\
\hline $\begin{array}{l}\text { 1. Menciptakan guru profesional } \\
\text { yang }\end{array}$ & $\begin{array}{l}\text { 1. Biaya } \\
\text { menempuh } \\
\text { mahal }\end{array}$ \\
\hline $\begin{array}{l}\text { 2. Meningkatkan } \\
\text { kesejahteraan } \\
\text { guru }\end{array}$ & $\begin{array}{l}\text { 2. Sosialisasi belum } \\
\text { maksimal }\end{array}$ \\
\hline $\begin{array}{l}\text { 3. Semua sarjana } \\
\text { non-kependidikan } \\
\text { bisa masuk PPG }\end{array}$ & $\begin{array}{l}\text { 3. Banyak guru yang } \\
\text { belum bisa keluar dari } \\
\text { zona nyaman }\end{array}$ \\
\hline
\end{tabular}

\section{1st Century Education}

Education in the 21 st century can also be called Education 4.0 or education era industrial revolution 4.0. with the teacher as the main role holder. The era of 21 st century educational transformation is a stream of change in which teachers and students will both play an important role in learning activities. The role of teachers is not only as a transfer of knowledge or teachers are the only learning resources that can do anything (teacher center), but teachers as mediators and active facilitators to develop the active potential of students in him (Rusman, 2018). Based on the results of the interview, it is known that some teachers have felt ready but others are not ready. Some fellow teachers 
also feel unprepared, stutter in technology and are reluctant to teach themselves to keep up with developments. However, all teachers agree that whether or not the teacher is ready to follow the changes according to the demands of the times. Students born in the millennial century have a different character and shift in value to the era of the teachers in the past. Teachers should be able to keep up with developments, not to be missed. In accordance with the saying "Educate your son according to his day". Therefore, teachers should be able to prepare themselves in equipping students. Thus, students have a sufficient supply of life in facing the future. The teaching and learning process is also a process that contains a series of actions of teachers and students on the basis of reciprocal relationships that take place in educational situations to achieve certain goals. Interaction between teachers and students is the main requirement for the teaching and learning process. In learning situations, it is the teacher who leads and takes full responsibility for his or her leadership. According to (Yunus, 2016) Learning activities are very important activities of the educational process. Teachers are educational implementers who have an important role in achieving educational success. Likewise, teachers have a very important effort in increasing student motivation.

According tp Uzer Usman in (Pangestika \& Alfarisa, 2015) specific teacher professionalism can be seen from 4 (four) indicators, namely: Mastering the foundation of education, namely recognizing educational goals, recognizing school and community functions, and recognizing the principles of educational psychology; Mastering teaching materials, namely mastering basic and secondary education curriculum teaching materials, mastering living materials; Compiling a teaching program, namely setting learning objectives, selecting and developing teaching materials, selecting and developing teaching and learning strategies, selecting appropriate learning media, selecting and utilizing learning resources, implementing teaching programs, creating an appropriate teaching and learning climate, arranging learning spaces, managing teaching and learning interactions; and Assessing the results and the learning process that has been implemented.

\section{$21^{\text {th }}$ Century Education}

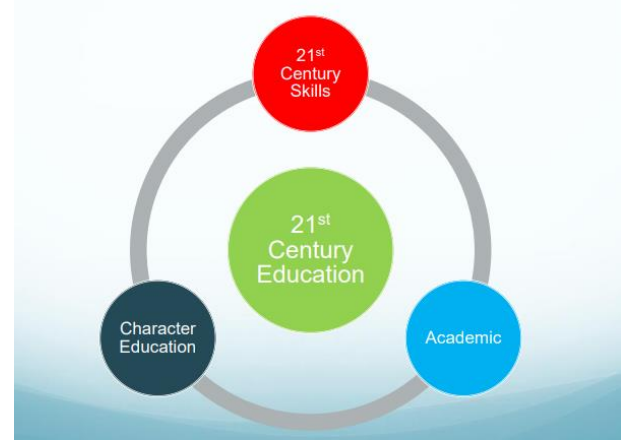

Gambar $1.21^{\text {th }}$ Century Education (source: google)

\section{Pembahasan}

Teacher professional education is education that develops and equips graduates with subject teacher competency standards so that graduates become professional teachers. According to (Disas, 2017) the teacher competency standard can be achieved through two stages of education, namely $\mathrm{S} 1$ education and teacher professional education which is carried out continuously. Competency standards for graduates in undergraduate education are academic mastery, while the competency standards to be achieved in the teacher professional education program are professional competences. As stipulated in the Teacher and Lecturer Law: Article 1, all teachers are required to become professional educators with the main task of educating, teaching, 
guiding, directing, training, assessing and evaluating students in early childhood education units through formal education, basic education, and middle education. As a professional educator. In addition to having a minimum academic qualification of S1, competence (pedagogic, professional, personality and social), teachers are also required to have an educator certificate (Kurniasih \& Sani, 2017). With this necessity, to achieve quality education, having an educator certificate is a must, even though there are many factors that determine to achieve this quality education. The explanation relating to the protection of teachers in Indonesia is divided into 4 (four) protections, namely legal protection, professional protection, occupational health and safety protection, and protection of intellectual property rights (Komara, 2016).

Improving the quality of education does not depend on the curriculum, but depends on the quality of teachers. Therefore, it is necessary to continue to improve the quality of teachers. Teachers as educators must continue to be educated to become teachers who can provide inspiration for students. Thus students can complete education with high quality accompanied by good character. Efforts that can be made by teachers in improving and developing their competence include, among others, by increasing the level of education towards a higher linear and relevant direction, participating in various education and training activities, actively participating in activities in KKG / MGMP, attending educational seminars, and actively reading books of professionals (Irwantoro \& Suryana, 2016). There really is no reason anymore for teachers not to make these efforts, especially for teachers who are certified. Teachers who have been certified will get a professional allowance, so that the status and condition of certified teachers should become motivation, stimulation, and deep awareness for every teacher to proactively strive to seriously improve their competence and performance for the advancement of the nation's national education.

The biggest challenge faced by the average teacher has to do with IT. Weaknesses in IT can be overcome by being willing to learn. Currently, many facilities are offered from both schools and outside parties to help teachers improve their IT skills. For example, schools hold e-module workshops, e-report cards, writing questions online, using android in learning, making interactive quizzes, making learning videos and so on (Retnaningsih, 2019). Meanwhile, according to (Walker, 2017), to become a teacher who is favored by students is a teacher who can recognize the characteristics of children who are of course different. In addition, by playing while learning, giving rewards after learning, making joint learning plans, and other activities so that students process learning well. To ensure the quality of a person's work is professional, it needs to be controlled. There are two forms of control and supervision in the profession, namely: (1) protection measures undertaken by the government through the exercise of authority in the field of public law; and (2) self-regulation, namely the implementation of control by one's own group through a professional code of ethics. Appart from that, Abdurrahman in (Rahman, 2014) explains that there are at least three elements of professional knowledge that are always self-reflective of the teacher, namely: content knowledge, pedagogical knowledge and content packaging knowledge in meaningful learning.

Professional development is the activity of teachers in the practice of science and knowledge, technology and skills to improve quality, both for the teaching and learning process and the professionalism of other education personnel (Putri \& Imaniyati, 2017). Professional development is the personal improvements that a person makes to achieve a professional plan. Profession is a position or ordinary job as well as other jobs. The development of the teaching profession is an important thing to pay attention to in order to anticipate changes and the magnitude of demands on the teaching profession, which mainly emphasizes mastery of science. Professional development can be defined as a long career process in which educators refine their teaching to meet student needs. Teachers are required to become members of professional organizations (article 41, paragraph 3). Through professional organizations, teachers can fight for their rights in professional protection, as stated in article 42-point c. Teachers are required to obey the professional code of ethics, which in practice is supervised by the Honorary Teacher 
Council (article 44, paragraph 1). With regard to the right to professional protection, the government guarantees the rights of teachers to obtain professional protection, as regulated in Law Number 14 of 2005 concerning Teachers and Lecturers, in Part Seven of Article 39 paragraph (4), which includes the following aspects: First, protection against termination of employment that is not in accordance with statutory regulations. Second, giving improper rewards. Third, restrictions in conveying views. Fourth, harassment of the profession. Fifth, other restrictions / restrictions that can hinder teachers from carrying out their duties. Meanwhile, according to (Walker, 2017) the main key to being a professional teacher is to be a happy and happy teacher. How teachers can make twoway communication well, make learning fun and always ask for students' opinions so that students will get a share of the educational process.

\section{KESIMPULAN}

To improve teacher professionalism in educational institutions, increase work motivation or work productivity, and provide various types of training and professional education to teachers are needed. In addition, government policies are also needed in developing human resources through the professionalization of educators and education personnel in an effort to improve the quality of teachers and the quality of education. For teachers who have received PPG certificates or have conducted trainings, it is necessary to pay attention to teachers who have not received certificates and have not conducted training. Teachers who have been certified will become an example for other teachers.

The implementation of online learning has obstacles / constraints both in terms of human resources and infrastructure. Network limitations, lack of training, lack of awareness and interest were cited as the main challenges faced. The obligation to learn online is a serious obstacle, especially for students from economically weak circles. Online learning in a number of regions in Indonesia is not running optimally, especially in remote areas with limited internet technology and networks. The readiness of school infrastructure, the ability of teachers to teach, and the availability of smartphone facilities are other problems in the application of online learning in Indonesia. Students also perceive that the school does not have a good program for the home learning system. Schools and teachers only give assignments in a row according to the lesson plan and subject matter in non-pandemic / normal conditions.

\section{DAFTAR RUJUKAN}

Alamsyah, M., Ahmad, S., \& Harris, H. (2020). Pengaruh Kualifikasi Akademik Dan Pengalaman Mengajar Terhadap Profesionalisme Guru. Journal Of Education Research, 1(3), 183-187.

Disas, E. P. (2017). Pengembangan Profesi Guru Dalam Meningkatkan Kinerja Guru. Jurnal Penelitan Pendidikan, 2(2), 158-166.

Hadis, A., \& Nurhayati B. (2014). Manajemen Mutu Pendidikan. Alfabeta.

Hidayat, S. (2013). Teori Dan Prinsip Pendidikan. Pustaka Mandiri.

Irwantoro, N., \& Suryana, Y. (2016). Kompetensi Pedagogik. Genta Group Production.

Ismaya, B. (2015). Pengelolaan Pendidikan. PT Refika Aditama.

Komara, E. (2016). Perlindungan Profesi Guru Di Indonesia. Mimbar Pendidikan: Jurnal Indonesia Untuk Kajian Pendidikan, 1(2), 151-160.

Kristiawan, M., \& Rahmat, N. (2018). Peningkatan Profesionalisme Guru Melalui Inovasi Pembelajaran. Jurnal Iqra': Kajian IImu Pendidikan, 3(2), 373-390.

Kurniasih, I., \& Sani, B. (2017). Kupas Tuntas Kompetensi Pedagogik (Teori Dan Praktik). Kata Pena.

Latiana, L. (2019). Peran Sertifikasi Guru Dalam Meningkatkan Profesionalisme Pendidik. Edukasi, 13(1), 1-10.

Pangestika, R. R., \& Alfarisa, F. (2015). Pendidikan Profesi Guru (Ppg): Strategi Pengembangan Profesionalitas Guru Dan Peningkatan Mutu Pendidikan Indonesia. Prosiding Seminar Nasional, 671-683.

Permendiknas. (2007). Standar Kompetensi Profesional. 
Putri, A. D. K., \& Imaniyati, N. (2017). Pengembangan Profesi Guru Dalam Meningkatkan Kinerja Guru. Jurnal Pendidikan Manajemen Perkantoran, 2(2), 202-211.

Rahman, B. (2014). Refleksi Diri Dan Peningkatan Profesionalisme Guru. Jurnal Paedagogia, 17(1), 1-12.

Retnaningsih, D. (2019). Tantangan Dan Strategi Guru Di Era Revolusi Industri 4.0 Dalam Meningkatkan Kualitas Pendidikan. Prosiding Seminar Nasional : Kebijakan Dan Pengembangan Pendidikan Di Era Revolusi Industri 4.0., 23-30.

Riyadin, S. (2016). Kebijakan Pengembangan Profesionalisme Guru Pns. Jkmp, 4(2), 219-234.

Rusman. (2018). Belajar Dan Pembelajaran Berbasis Komputer. Mengembangkan Profesionalisme Abad 21. Alfabeta.

Supandi, A., Sahrazad, S., Wibowo, A. N., \& Widiyarto, S. (2020). Analisis Kompetensi Guru: Pembelajaran Revolusi Industri 4.0. Prosiding Samastra: Seminar Nasional Bahasa Dan Sastra Indonesia, 1-6.

Wahyono, P., Husamah, H., \& Budi, A. S. (2020). Guru Profesional Di Masa Pandemi COVID-19: Review Implementasi, Tantangan, Dan Solusi Pembelajaran Daring. Jurnal Pendidikan Profesi Guru, 1(1), 51-65.

Walker, T. D. (2017). Teach Like Findland (Mengajar Seperti Finlandia). Gramedia Widiasarana Indonesia.

Yunus, M. (2016). Profesionalisme Guru Dalam Peningkatan Mutu Pendidikan. Lentera Pendidikan, 19(1), 112-128. 